\title{
The Vertical Distribution of Aerosol in the Lower Atmosphere Observed by a Lidar
}

\author{
by \\ Keikichi Naito, Isao Tabata and Yoshio Yokota \\ Meteorological Research Institute, Tokyo \\ (Received October 8, 1968)
}

\begin{abstract}
The vertical structure of the aerosol content observed by a lidar in the lower atmosphere is to be related to the thermal structure of the atmosphere, but no definite relationship has yet been found between lidar and radiosonde data in spite of many suggestions made concerning this subject since the advent of lidar. Some investigation is here made on it by the use of lidar data obtained only on clear days with light winds.

Aerosol particles are found in late afternoon to be accumulated by atmospheric convection in the upper levels (700-1,600 meters or so), of which the boundary is mostly determined by the maximum mixing depth obtained with the help of the temperature profile given by radiosonde ascent and the maximum surface temperature. Lidar observations clearly visualize the atmospheric convection through tracers of aerosol particles. Both in the morning and in early afternoon it is seen that the "plume" or "flare" is one of the main forms in the convection. The vertical distributions of aerosols both in the morning and in the afternoon are characterized and classified in view of the convection based on the lidar data.

Many discontinuities of lidar echoes are found to be present throughout the lower atmosphere in the form of either large layers or solitary patches; they are considered to be important in the "layerreflection" in the microwave propagation.
\end{abstract}

\section{Introduction}

The vertical structure of the aerosol content observed by a lidar in the lower atmosphere is to be related to the thermal structure of the atmosphere, and the discontinuity of lidar echoes is believed to be associated with the temperature inversion (Ligda, 1964; Collis, 1965; Hamilton, 1966; KarNey et al., 1967).

Recently VIEZEE and OBLANAS (1967) have reported detailed observations by lidars, but in their results no good correspondence exists between the sharp decreases of echo 
and the temperature inversions. They ascribed this lack of correspondence to the fact that their temperature data were obtained by radiosonde observations which were made some 20 miles away from the lidar site at a different time and on different scales.

We installed a ruby lidar recently at the Meteorological Research Institute (M.R.I), Tokyo, of which the equipment parameters are described in the Appendix. By the use of the lidar we have had several interesting observations which are used to investigate the relation between the lidar echo and the thermal structure of the atmosphere, although we have not been able to make extensive observations yet because of some points to be improved in our lidar system. The analyses presented in this paper are limited to cases on clear days with light winds, and this limitation will not be frequently mentioned hereafter.

\section{Lidar data on a clear afternoon and the thermal structure}

Fig. 1 shows the vertical section of contours of range-normalized values of relative intensity of lidar echo obtained by a vertical beam-swing which was made on a clear afternoon with light wind in autumn. The range-normalization here means that the

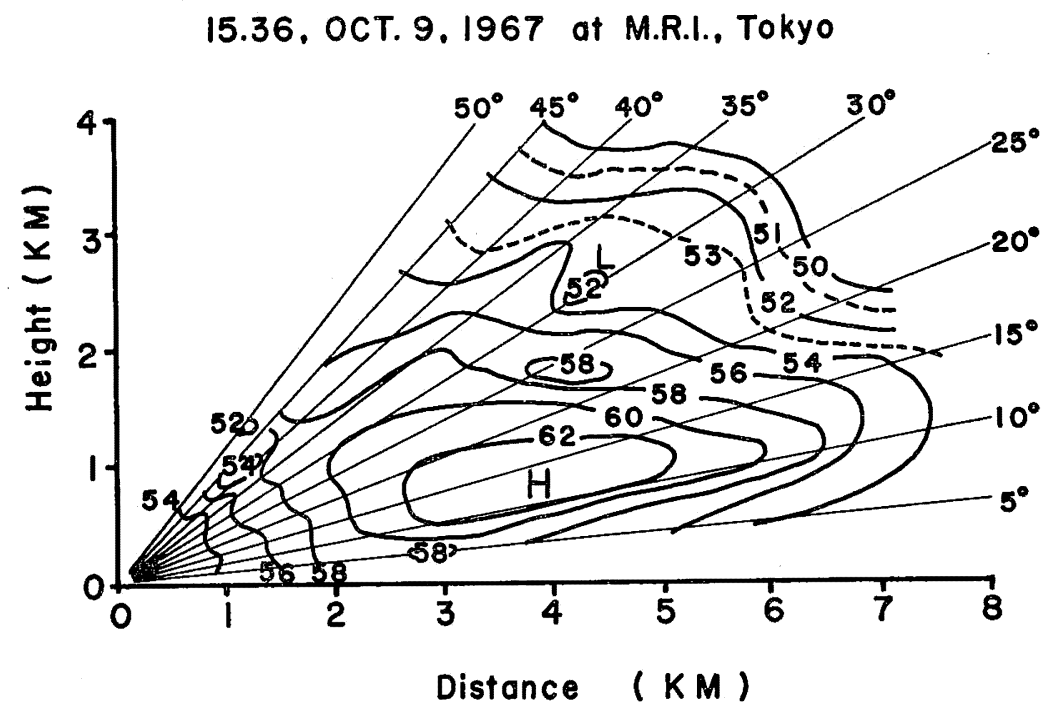

Fig. 1. Vertical section of contours of the range-normalized lidar echo or aerosol concentration (in $\mathrm{dB}$ )' in the late afternoon. $H$ indicates the high concentration and $L$ the low concentration.

echo intensity is multiplied by the square of distance and the range-normalized relative value expressed in $\mathrm{dB}$ is used hereafter for the echo intensity, unless there are special specifications concerning the expression.

The vertical section in Fig. 1 indicates that the distribution of aerosol content has a cloud-like pattern and is not uniform even in the horizontal direction. The shape of contours in the right half of the vertical section may indicate the presence of attenuation of lidar waves in their propagation through the atmosphere. 
The mean vertical distribution of lidar echoes shown in Fig. 2 is derived from the vertical section in Fig. 1. In the studies mentioned above, the profiles of lidar echoes were obtained by observations with fixed elevation angles. Because of the attenuation,

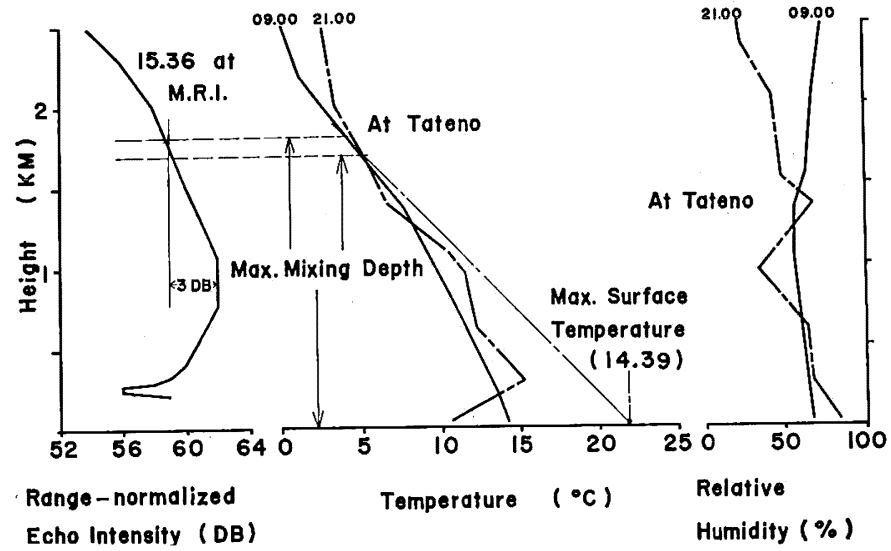

Fig. 2. Profiles of the lidar echo, temperature and humidity on the same day as in Fig. 1.

however, this method of obtaining the profile may be subject to serious errors. If observations are made with high elevation angles in order to minimize the effect of attenuation, no information is obtainable in the low level where the transmitter beam is not intersected completely by the receiver beam. Although the effect of attenuation is inherent in any form of observation, it is one of the best ways to derive the profile from the vertical section of contours as shown in Fig. 1, because we can thus decrease the effect of attenuation.

The temperature and humidity data afforded by a radiosonde ascent at Tateno, which is located at about fifty-five kilometers distance from our lidar site, are also shown in Fig. 2. It is seen in this figure that the lidar echo or, roughly speaking, the aerosol content does not correspond to any features of the temperature profile. The humidity data show little condensation in the layer under consideration. Thus, as stated in the studies above, the following question may be asked: is it not found that even the smoothed profile of the aerosol content is related to the temperature data, unless some simultaneous, special sounding of temperature is made at the same place as the lidar site?

As is easily seen in a visual observation made at the top of a high tower, aerosol particles start to ascend, owing to convection, from the layer very close to the ground at sunrise on a clear day with light wind. The airborne particles are still at lower levels, i.e. as high as the tops of ordinary buildings, at about seven o'clock in the morning in early winter at Tokyo. By about nine o'clock, however, the altitude of the airborne particles, now in a form of haze, reaches as high as about three hundred meters (which is level with one of the observatories of the Tokyo Tower)*. Accord-

* The visual observation at the Tokyo Tower was made by our colleagues, Messrs. K.

Takahashi and T. Mizoguchi. 
ing to the experiences of some airplane pilots, the altitude becomes several hundred meters or more by noon and often exceeds a thousand meters in the afternoon.

These experiences suggest that the aerosol particles in the lower atmosphere observed by a lidar are largely particulate matter transported upward by convection from the ground after sunrise. The air goes upward from the warmer spots of the ground surface which is heated irregularly by the sun. Approximately, the ascending of air takes place dry-adiabatically and stops at a level where a dry-adiabatic line starting from the surface temperature intersects the environmental temperature profile given by radiosonde observation. The convection activity is maximum when the maximum surface temperature occurs. Therefore, in the late afternoon the height of the upper boundary of the layer of maximum aerosol content should be determined by the level where the dry adiabatic line passing through the maximum surface temperature intersects the temperature profile. This level is what is called the maximum mixing depth (M.M.D.).

In fact, Fig. 2 shows that, if the upper boundary is defined as a level at which the aerosol content is $3 \mathrm{~dB}$ down from the (upper) maximum content in the smoothed profile, the height of the the boundary is nearly equal to the M.M.D. In our case the maximum surface temperature is not obtained at M.R.I., but at the Meteorological Agency, $10 \mathrm{~km}$ distant from M.R.I., while the temperature profile is at Tateno $55 \mathrm{~km}$ distant. Inspite of these unfavourable conditions in obtaining the temperature data, all the observations we have made on clear afternoons with light winds show a good correlation between the upper boundary of the aerosol layer and the M.M.D.

\section{A model of the distribution of the aerosol content in the afternoon in an urban area}

As time elapses in the morning, the surface temperature rises and quickens atmospheric convection. The industrial activities accelerate the production of particulate matter related to the atmosphere pollution, especially in an urban area. Consequently, much aerosol is accumulated in the upper layer in the M.M.D. This upper accumulation of aerosol continues into the early afternoon. It is supposed that in the late afternoon a rather clear boundary is likely to be formed around the top of the M.M.D. in case of light wind. This is the situation of the layer indicated by $A B$ in Fig. 3, which is, intended to illustrate a model of the distribution of aerosol content in the late afternoon in an urban area.

Airborne particles in the layer $\mathrm{BC}$ in Fig. 3 are considered to be mostly those transported from the ground early in the morning. Since the rate of production of such particles is smaller in the early morning than in the late morning, the concentration of airborne particles in the layer $\mathrm{BC}$ should be smaller than that in the layer $\mathrm{AB}$.

Below the level $\mathrm{C}$, enough information is not available in our lidar observation because of too low elevation. However, the aerosol content is to increase below the level, since the lowest layer DE in Fig. 3 is supposed to be rich in airborne particles as described in the following.

NAITO and HAY (1966) found from experiments on smoke puffs and trials that 


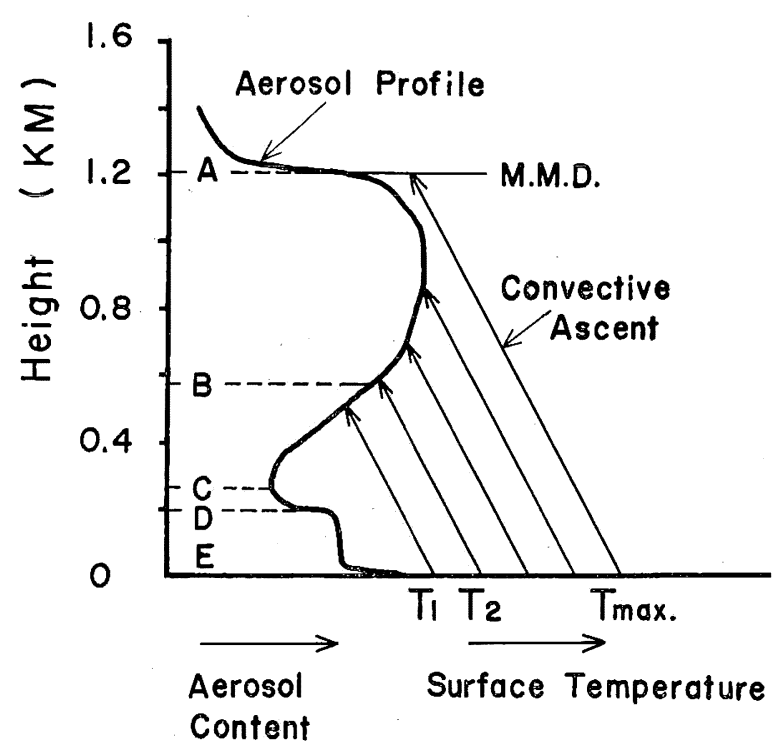

Fig. 3. A model of the aerosol profile in the late afternoon on a clear day with light wind in an urban area.

the turbulent flow dominates up to a level of about $200 \mathrm{~m}$, such as is indicated by D in Fig. 3, and the rather laminar flow dominates above the level $\mathrm{D}$ in case of clear weather. Therefore, the airborne particulate matter is presumably stirred and mixed up in the layer DE by the turbulent flow combined with the convection and they may be distributed more or less uniformly.

Whether the aerosol concentration is larger in the layer $\mathrm{AB}$ than in the layer DE or not would be determined by the time-variation of source intensity of the atmospheric pollution and such meteorological conditions as the convection and wind. It should be noted, however, that if the convection is vigorous in the morning, the horizontal visibility seems sometimes better than the slant visibility in the afternoon.

Those considerations described above lead to a model of the smoothed vertical distribution as shown in Fig. 3. However, it should be mentioned here that the effect of temperature inversion on the distribution is not taken into account in Fig. 3.

\section{Lidar data in the morning}

Fig. 4 is a typical example of the vertical section of contours of lidar echoes on a fine morning when the convection is considered to be vigorous. Fig. 5 shows the echo profiles at different places which are derived from the vertical section in Fig. 4. Temperature and humidity data obtained at Tateno are also shown in Fig. 5.

In Fig. 4, the contours are rather vertical than horizontal. This is a fact that would be expected from a consideration of the particulate matter on the convective transport in the morning. It is also to be noted in the figure that there is a high concentration of aerosol which shapes a flare or plume rising from the ground. This may suggest that the "plume" or "flare" is one of the main forms in the atmospheric con- 


\subsection{Oct. 19, 1967, at M.R.I., Tokyo}

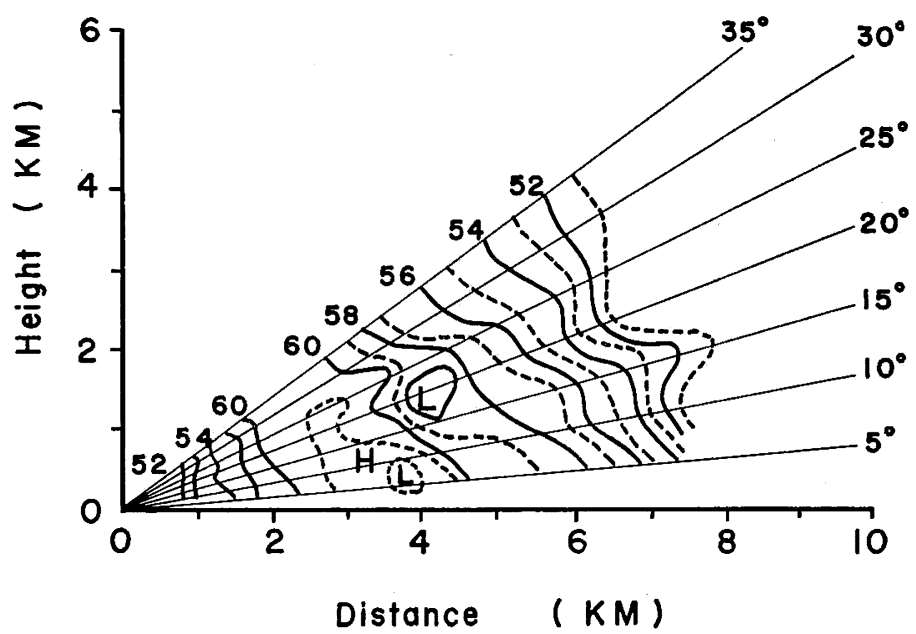

Fig. 4. Vertical section of contours of the lidar echo (in $\mathrm{dB}$ ) on a clear morning.

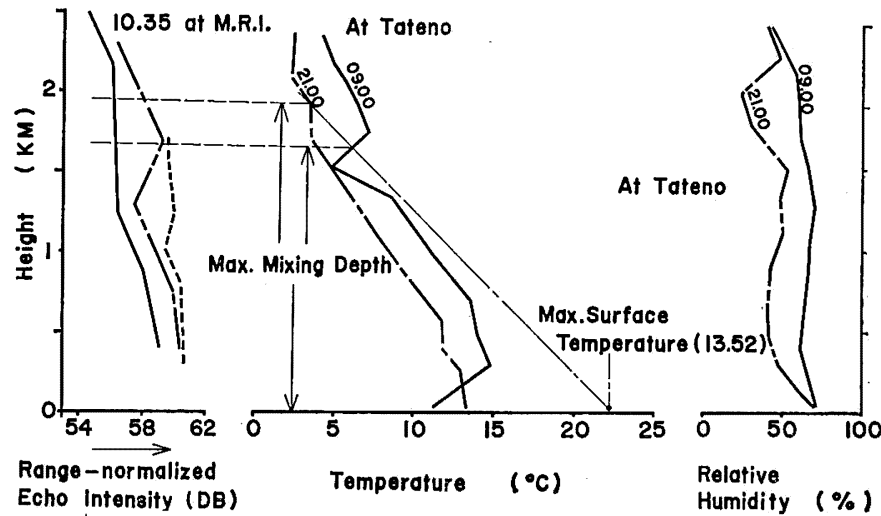

Fig. 5. Profiles of the lidar echo, temperature and humidity on the same day as in Fig. 4.

vection in the scale under consideration (NAITO, 1965). It seems that the "flare" shape is seen also in a picture of RHI scope observed by an ultrasensitive microwave radar (HARDY, 1968). The general tendency of gradual decrease in aerosol content with height in Fig. 5 is easily explained by the upward transport of particles in the convective plume or flare, and the tendency is considered to be one of the main features of the smoothed profile at the mature stage of convection.

In order to form a convective circulation in the atmosphere, there must be an area of downward flow of air outside the "flare". From our observations the horizontal dimension of the downward flow usually seems much larger than that of the "flare", so that the downward speed must be much smaller than the upward speed 
in the "flare". Therefore, it is considered that the effect of the downward motion of air is not usually present in the morning profile of aerosol.

It should be added that, according to the Tateno pibal observation made around 14:00 JST on the same day, a light wind was generally blowing from right to left up to an altitude of about $3 \mathrm{~km}$ in Fig. 4. This fact would explain the tilting of the contours.

The convective "bubbles" were not identified by our lidar observations. There are sometimes seen small, circular regions of high aerosol content in the vertical section as shown in Fig. 4. They may be either the cross-sections of the convective flares or the convective bubbles or the inhomogeneities of aerosol excess merely floating in the air. If they are bubbles, then they must make the upward motions which are, however, very difficult to observe by a lidar at the present stage of technical development.

\section{Discontinuities in lidar echoes}

The sharp increase, decrease, peak and crevasse in the lidar echo presented on the A-scope of the lidar receiver are called discontinuities in this paper for convenience. Such discontinuities are plotted with small black circles on lines showing various elevation angles in the vertical section in Figs. 6 and 7. If, judging from the echo patterns on the A-scope, the adjacent circles are considered to be related to each other, they are connected with a solid, heavy line. The solitary circles in the figure are discontinuities of so small sizes hat no adjacent circles are related to them.

If the scatterers are such large particles as insects, the corresponding echoes would be very large peaks and easily indentified. We have not observed such echoes yet.

Fig. 6 corresponding to the case in Fig. 1 indicates may horizontally discontinuous layers after the vertical motion of convection is over, but it is difficult to find out any specific relations between the horizontal discontinuities and the temperature

15.36. Oct. 9. 1967, at M.R.I., Tokyo

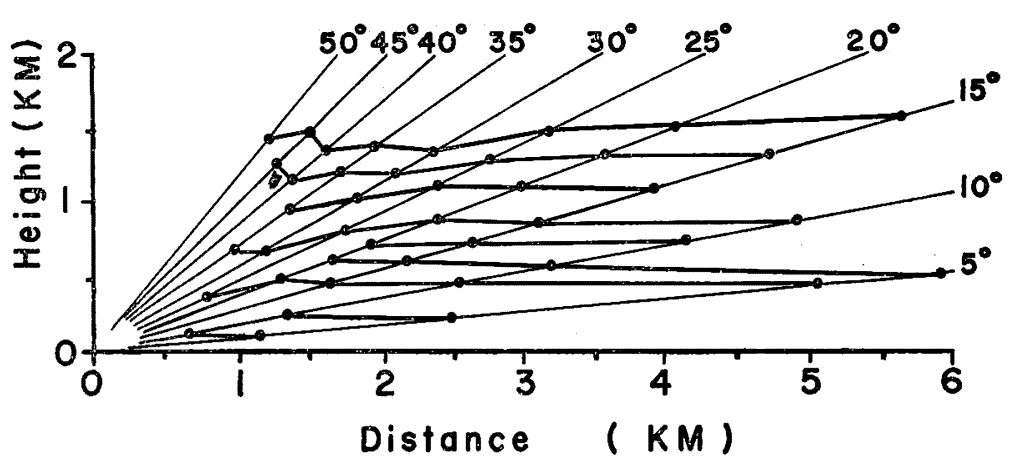

Fig. 6. Discontinuities of the lidar echo in the late afternoon on the same day as in Fig. 1. 


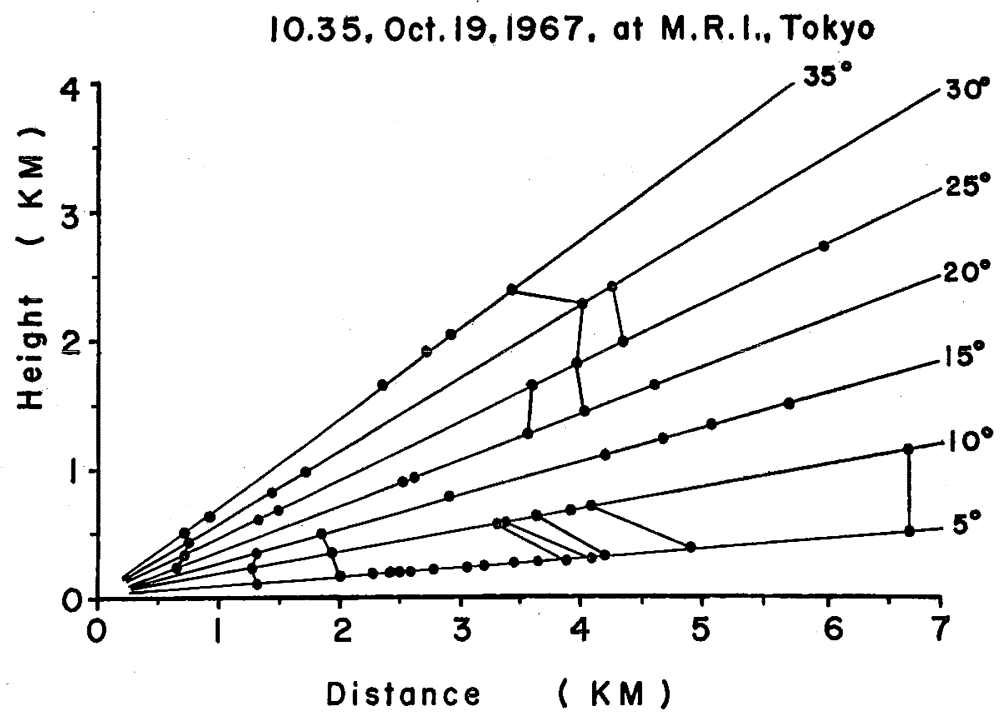

Fig. 7. Discontinuities of the lidar echo on the morning of the same day as in Fig. 4.

and humidity profiles obtained by radiosonde ascent.

Fig. 7 corresponding to the case in Fig. 4 indicates some slant discontinuities which seem to be the sides of the convective flare. In addition, there are many solitary discontinuities in this case.

The inhomogeneities in the temperature, humidity and refractivity in the lower atmosphere should be considered quite similar to those of aerosol. Therefore, the presence of many discontinuities forming large layers or solitary patches may suggest the important role played by the "layer-reflection" in microwave propagation, especially beyond the horizon.

So far we have not considered the effect of temperature inversion, since we have not had many adequate observations yet, because of the malfunctions of our lidar. However, the role of temperature inversion is easily understood by a consideration of the adiabatic ascent of air transporting airborne particles from the ground. Fig. 8 shows the adiabatic ascent of air due to convection in conjunction with a model profile of temperature with inversion and the resulting profile of the aerosol content. In this figure, the upward flux of convection is assumed to be doubled after 10:00 o'clock.

It is clear in this figure that temperature inversion always causes a sharp increase at the lower boundary of the inversion and a sharp decrease at the upper boundary, but the reverse is not always the case, that is, the aerosol discontinuity does not always correspond to temperature inversion.

\section{Conclusions}

From the nature of our observations the following conclusions are good only 


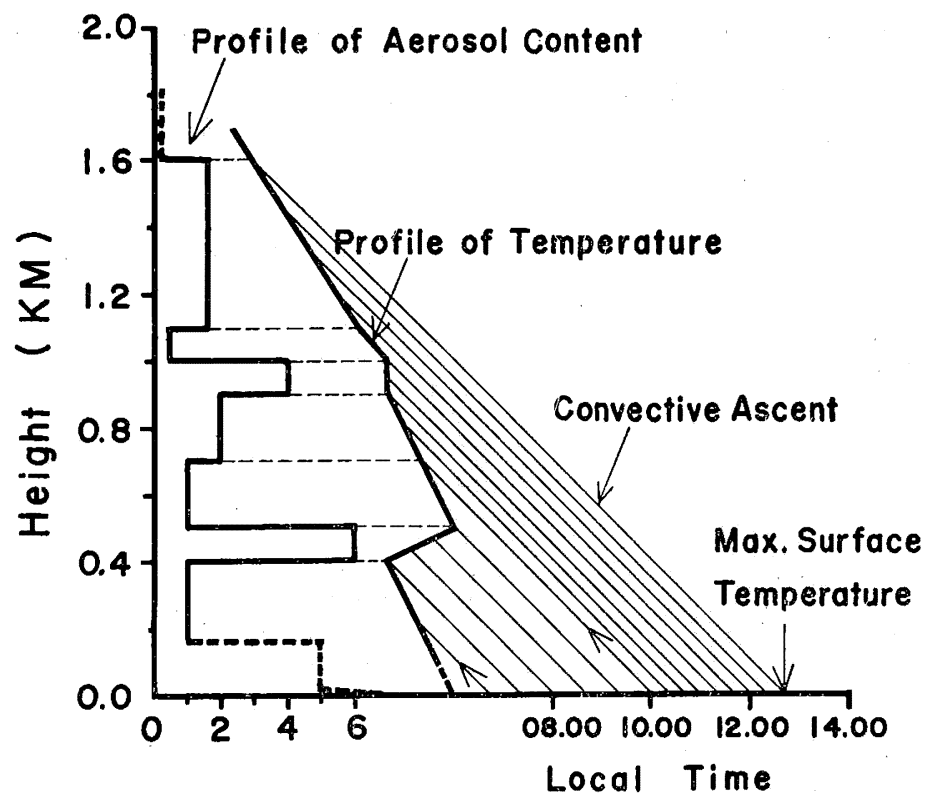

Fig. 8. A temperature profile with inversion and the corresponding profile of aerosol content. The convective upward flux is doubled after 10:00 local time.

for a fine day with light wind.

In the atmospheric convection, the "plume" or "flare" is found in lidar data to be one of the convection forms in the lower atmosphere, and the other forms are not identified. The convection starts at sunrise and continues until about the occurrence of the maximum surface temperature.

Aerosol particles are continuously transported by the convective air from the ground to the upper levels both in the morning and in the early afternoon, when the contours of range-normalized echo or aerosol content are rather vertical than horizontal and the smoothed profile of aerosol decreases gradually with height. These distributions of aerosol in the lower atmosphere are easily explained by the convective "plume" or "fiare".

In the late afternoon when the vigorous convection is considered to be over, the transported particles are accumulated in the upper layer to form themselves into something like a horizontally stratified cloud. The height of the accumulated aerosol defined as the " 3 -dB-down" boundary is found mostly equal to the maximum mixing depth derived from the radiosonde data (obtained at a fifty-five $\mathrm{km}$ distance) and the maximum surface temperature (obtained at a ten $\mathrm{km}$ distance). A model of the smoothed profile of aerosol is proposed in Fig. 3. We have not made an adequate lidar observation in a significant temperature inversion and no relations have been found between the lidar profile and the inversion. Some consideration was, however, given to the effect of temperature inversion upon aerosol distribution: it may be suggested that temperature inversion causes a peak or discontinuities in the aerosol profile, but the discontinuities in the profile do not always correspond to the tem- 
perature inversion.

There are so many discontinuities indicated by tracers of aerosol particles in the lower atmosphere that the "layer-reflection" is considered to play an important role in the microwave propagation.

Acknowledgement-The writers wish to express their thanks to their colleagues for their technical assistance and to Dr. $N$ KoDArRA, head of the Weather Instrument Laboratory of the Meteorological Research Institute, for kindly discussing the problem with the writers.

\section{References}

Collis, R. H., 1965: Use of lidar in atmospheric research. Paper presented at 2nd Annual Meeting, AIAA, San Francisco, July 26, 1965.

Hamilton, P. M., 1966: The use of lidar in air pollution studies. Air and Wat. Pollut. Int. J. Pergamon Press, 10, 427-434.

HARDY, K. R., 1968: CPS-9-Radar investigation of clear-air convection. Proc. of the 13th Conference on Radar-Meteorology, AMS, Boston, 236-240.

KARNEY, J. L. et al., 1967: Laser radar returns from the lower troposphere compared with vertical ozone distributions. Tech. Memorandum PMR-TM-67-2, Pacific Missile Range, Calif.

LigDA, M. G. H., 1964: Meteorological observations with lidar. Proc. of the World Conf. on Radio Meteorology, AMS, Boston, 482-489.

NAIto, K., 1965: On radar angels. Proc. of the International Colloquium, Moscow, June 15-22, 1965, 262-268.

NAITO, K. and D. R. HAX, 1966: Internal gravity-shear waves in the troposphere. Part 3 Perturbation of smoke trails. Canad. J. Phys., 44, 2287-2291.

ViezeE, W. and J. Oblanas, 1967: Lidar-radar lower atmospheric observations. Tech. Rep. AD-647463, Stanford Res. Inst., Menlo Park, Calif.

\section{Appendix}

The lidar equipment parameters in M.R.I. are tabulated in the following.

\begin{tabular}{|c|c|c|c|}
\hline \multicolumn{2}{|c|}{ Transmitter } & \multicolumn{2}{|c|}{ Receiver } \\
\hline Laser Material & $\begin{array}{l}\text { Ruby (Oscillation and } \\
\text { Amplification Rods) }\end{array}$ & Optics & $\begin{array}{l}\text { Cassegrain Reflector } \\
(450 \mathrm{~mm} \phi)\end{array}$ \\
\hline Wavelength (Å) & 6943 & Beam Width (mrad) & $\begin{array}{l}5 \text { (Variable Field of } \\
\text { View) }\end{array}$ \\
\hline Output Energy (J) & 3 & Predetection Filter & \\
\hline Pulse Width (ns) & 30 & $\begin{array}{l}\text { Wavelength Interval } \\
(\AA)\end{array}$ & $<20$ \\
\hline Optics & Refractor $(150 \mathrm{~mm} \phi)$ & Detector & $\begin{array}{l}\text { Photomultiplier } \\
\text { (RCA 7326) }\end{array}$ \\
\hline Beam Width (mrad) & 1 & Type of Receiver & Linear \\
\hline Firing Rate (ppm) & $12,6,2,1$, (and manual) & Display & A-scope \\
\hline Q-switch & Rotating Prism & & 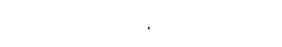 \\
\hline
\end{tabular}




\title{
ライタ（レーザレーダ）観測による下層大気内エーロゾルの垂直分布
}

\author{
内藤恵吉, 田端 功, 横田良夫
}

ライダ（レーザレーダ）はエーロゾル粒子を十分検出するから，ライダの出現以来エーロゾル浱度の垂直

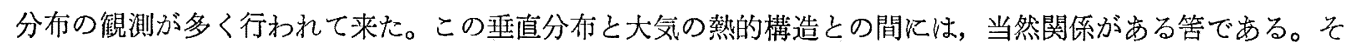
こで, ライダとラジオジンデのデータの間の関係を求めようと, 多くの努力がなされて来たが, 温度逆転層 との関係すらも十分実証されていない。本論文では，啨れた風の弱い日に限定して，ライダ観測から下層大 気 (2〜3 km 位まで) 飞抢けるこの種の問題を考察した。結論は次の通りである。（1)エーロゾルをトレー サーとして刘流を観察すると，午前中搞よび正午前後のように対流の盛んなときは，プリューム（plume） またはフレア (flare) の形で, 対流上昇・輸送が行なわれることが認められる。これは, エーロゾルの分布 が, この期間には高度とともにゆるく減ずる事実をよく説明しうる。対流に招ける熱気泡理論では, この分 布を説明するのに容易ではない。(2)対流は日出とともに始まり, 地上気温最大時が対流輸送最大と考兄ら れる。従って, 地上気温最大值を通る乾燥断熱線と, ラジオゾンデによる温度垂直分布との交点, すなわわ, 最大混合高度が，地上付近から対流によって上方に輸送されたェーロゾルの境界を，近似的に与古ることに なる。事実, 午後遅くなったときのライダ観測てよると, エーロゾル分布の上限は最大混合高度で与えられ ている。さらに，大気下層に括けるェーロゾル分布の一模型が提案されている。(3)ライダェコーの不連続部 は, 非常に広範囲 (5 $\mathrm{km}$ 以上) のほぼ水平層をなするのから, 数 $100 \mathrm{~m}$ 以下の不連続層のものまで, 傾斜 するもの, 水平のものを含め, つね水かなり存在する。このような不連続性の存在は, 極超短波伝搬に和け る「層反射」の有用性を暗示するものと思われる。午前中すなわち対流の盛んなときは，あまり大きな層は なく, 数多いものは小さいものである。また, 午後遅く対流の添涪止んだときは, 大さな水平層が多く, 午 前中と明らかな差異がある。(4)温度逆転層がエーロゾル分布に及ぼす影響について, 模型的に考察した。そ の結果, 温度逆転層は必ずェューの急激な増大また減少を生ずるが, ェコーの急激字増大, 減少また一般に 不連続は, 必ずしも温度逆転に対応しないことが明らかにされた。 